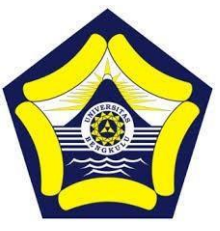

JOLL 4 (2) (2021)

Journal of Lifelong Learning

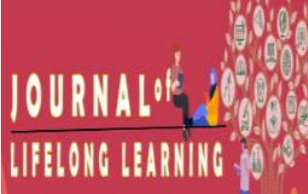

\title{
Manajemen Pemberdayaan Bidang Ekonomi di Masjid Baitul Atieq
}

\author{
Miksi Hardianto ${ }^{1}$, Agus Zainal R², Suardi Jasma ${ }^{3}$ \\ Pendidikan Nonformal, Universitas Bengkulu \\ miksihardianto@gmail.com, aguszainal@unib.ac.id, suardijasama@unib.ac.id
}

Abstrak

Program ekonomi dan sosial pengurus masjid Baitul Atieq memberikan manfaat terhadap pemberdayaan ekonomi jamaah terutama saat pandemi covid-19 saat ini. Maka penelitian ini bertujuan mendeskripsikan tentang peranan manajemen Masjid Baitul Atieq dalam pemberdayaan ekonomi jamaah. Peneliti ini menggunakan metode penelitian kualitatif dengan pendekatan deskrisptif. Teknik pengumpulan data yang di gunakan menggunakan wawancara, observasi, dan dokumentasi. Teknik validasi menggunakan trianggulasi. Yakni trianggulasi waktu, trianggulasi subjek, dan trianggulasi teknik. Hasil penelitian ini menunjukkan bahwa pengurus masjid Baitul Atieq telah memberikan kemudahan dan pemberdayaan ekonomi kepada jamaah berupa peminjaman modal uang 2 juta untuk 10 orang dan memberikan bibit ikan lele supaya jamaah bisa mengembangkan ternak ikan lele di rumah masing-masing.

Kata kunci : Pengurus Masjid,Manajemen Masjid, Permberdayaan.

\begin{abstract}
The economic and social program of the Baitul Atieq mosque management provides benefits for the economic empowerment of the congregation, especially during the current COVID-19 pandemic. So this study aims to describe the role of Baitul Atieq Mosque management in the economic empowerment of the congregation. This researcher uses a qualitative research method with a descriptive approach. Data collection techniques used using interviews, observation, and documentation. The validation technique uses triangulation. They are time triangulation, subject triangulation, and technique triangulation. The results of this study indicate that the Baitul Atieq mosque management has provided convenience and economic empowerment to the congregation in the form of lending capital of 2 million for 10 people and providing catfish seeds so that congregations can develop catfish farms in their respective homes.
\end{abstract}

Keywords: caretakers, Mosque Management, Empowerment.

\section{PENDAHULUAN}

Masjid merupakan tempat kaum muslimin beribadah dan mendekatkan diri kepada Allah SWT, yang memiliki kekuatan tersendiri bagi umat islam dan memberikan perubahan yang besar bagi kehidupan sosial. Masjid adalah salah satu tempat yang sangat sakral dan sangat penting bagi umat Islam. Keberadaan masjid tidak hanya sebagai tempat bersujudnya makhluk kepada tuhannya Allah SWT sang pencipta alam semesta tetapi juga sebagai pusat peningkatan kualitas hidup manusia (Mustaming, 2012). Tidak heran jika masjid dianalogikan sebagai representasi derajat hubungan manusia dengan Allah SWT dan juga antara manusia dengan manusia dimana pengukurannya bergantung kepada taraf iman manusia, makin tinggi iman maka 
makin makmur suatu masjid ataupun sebaliknya.

Masjid hingga saat ini masih tetap berfungsi, tetapi dalam pergerakkannya tidak lagi terarah sesuai fungsi, jika tidak dimanfaatkan dengan baik. Masjid merupakan pusat kegiatan kaum muslimin. Ibarat jantung bagi tubuh, ia merupakan tempat pemompa kualitas kaum muslimin. Dari sanalah seharusnya kaum muslimin merancang masa depannya, baik dari lini diin (agama), ekonomi, politik, sosial dan seluruh sendi kehidupan, sebagaimana para pendahulunya memfungsikan masjid secara maksimal (Faruq, 2010: 5).

Umat Islam khususnya di Bengkulu cenderung memahami bahwa masjid adalah tempat suci yang didalamnya hanya dibolehkan untuk digunakan tempat beribadah (shalat) saja dan tidak dapat dicampurbaurkan dengan aktivitas-aktivitas yang berhubungan dengan permasalahan-permasalahan sosial, seperti politik, ekonomi, budaya, adat dan sebagainya. Adanya pandangan bahwa semua pekerjaan yang berhubungan dengan masjid tidak memiliki keuntungan material sehingga orang melakukan secara tidak serius (Hutomo, 2000).

Kondisi tersebut akan mengakibatkan suatu perbedaan ibadah dan muamalah yang semestinya berjalan secara beriringan dan harmonis karena keduanya merupakan suatu sistem batang tubuh yang tidak bisa dipisahkan. Masjid sebagai pranata sosial Islam sekaligus media rahmatan 'lil alamin hanya akan mewujudkan rahmat dan barokah yang di inginkan jika masjid menjalankan peran dan fungsinya.

Peranan manajemen masjid dalam bidang ekonomi jamaah. Ekonomi dan masjid selalu menjadi hal yang sebenarnya adalah satu kesatuan dalam kehidupan masyarakat. Menurut Dewan Masjid Indonesia (DMI) ada tiga fungsi masjid pertama, masjid dapat difungsikan sebagai tempat ibadah,baik ibadah mahdhah, maupun ibadah sosial. ibadah mahdhah adalah ibadah yang langsung kepada Allah SWT seperti shalat, mengaji dan ibadah lainnya. Sedangkan sebagai pusat ibadah sosial, masjid dapat difungsikan sebagai pengelola zakat, wakaf, membangun ukhuwah islamiyah, menjaga kebersihan, kesehatan bersama dan membantu peningkatan ekonomi jamaah. Kedua, memanfaatkan masjid sebagai pusat pengembangan jamaah melalui sarana dan prasarana yang dimiliki masjid seperti khutbah, pengajian, kursus keterampilan yang dibutuhkan oleh jamaah. Dan yang ketiga, membina persatuan umat. Keagungan masjid tidak terletak pada keindahan bangunan fisiknya saja, melainkan bagaimana upaya memberdayakan masjid sebagai pusat pemberdayaan umat dan pengembangan peradaban (Bahtiar, 2017:83).

Fungsi mesjid dalam membina persatuan umat dapat ditinjau dari berbagai program yang dijalankan secara rutin. Berbagai program mesjid untuk kepentingan umat telah banyak digulirkan secara berkelanjutan. Mesjid memanfaatkan dana yang boleh digunakan secara syari'ah dengan pertimbangan dewan pengurus mesjid masing-masing.

Masjid menerima sumbangan dari masyarakat dalam bentuk infaq, shodaqoh, wakaf, dan bentuk dana lainnya sebagai sumbangan yang sah. oleh ajaran Islam. Donasi tersebut digunakan untuk membangun dan memelihara infrastruktur masjid dan fasilitas, membiayai pelayanan ibadah Islam, memberikan pelayanan pendidikan agama Islam, dan memberikan pelayanan sosial dan ekonomi dalam rangka meningkatkan kesejahteraan dan kualitas hidup masyarakat; muslim (Asrori dkk, 2021: 56).

Aktivitas yang dilakukan pengurus mesjid dalam bidang ekonomi saat ini, menjadi suatu program yang sangat dinanti dan diharapkan masyarakat. Pandemi Covid-19 yang telah melanda dunia selama 2 tahun sangat berdampak pada kehidpan ekonomi masyarakat. Pandemi covid-19 menyebabkan banyak sekali dampak yang dirasakan oleh pemerintah bahkan masyarakat kecil sekalipun. Salah satu dampak yang memiliki pengaruh yang sangat besar yakni masalah 
perekonomian. Pertumbuhan ekonomi global juga menurun ditandai dengan PDB dunia yang menurun di angka $2 \%$. Perekonomian Indonesia ke depan akan sangat bergantung pada proses penanganan pandemi ini (Suryani, 2021: 1591).

Kontribusi mesjid dalam aktivitas bidang ekonomi untuk pemberdayaan ekonomi jamaah diperlukan dan tepat sebagai salah satuu upaya menghadapi masalah ekonomi masyarakat akibat dampak pandemi Covid-19 dan melatih masyarakat dalam memperbaiki perekonomian pada masa yang akan datang.

Peneliti menggunakan metode penelitian kualitatif. Desain penelitian yaitu penelitian deskriftif kualitatif karena dilakukan pada kondisi yang alamiah. Metode penelitian kualitatif adalah metode penelitian yang digunakan untuk meneliti pada kondisi obyek yang alamiah, dimana peneliti sebagai instrumen kunci, teknik pengumpulan data dengan trianggulasi (gabungan), analisis data bersifat induktif, dan hasil penelitian kualitatif lebih menekankan makna dari pada generalisasi (Sugiy0no, 2020: 9).

Objek alamiah yang dimaksud adalah objek yang apa adanya, tidak dimanipulasi oleh peneliti sehingga kondisi pada saat peneliti memasuki objek, setelah berada di objek dan setelah keluar dari objek relatif tidak berubah.

Penelitian di laksanakan dalam kurun waktu dua minggu, yakni sejak tanggal 06- 20 Juli 2021. Teknik pengumpulan data yang digunakan dalam penelitian ini yaitu: (1) observasi. observasi adalah dasar semua ilmu pengetahuan. Para peneliti hanya dapat bekerja berdasarkan data, yaitu fakta mengenai dunia kenyataan yang diperoleh melalui observasi (Nasution dalam Sugiyono, 2020: 106). (2) Wawancara. Wawancara merupakan hatinya penelitian sosial. Bila anda lihat jurnal dalam ilmu sosial, maka akan anda temui semua penelitian sosial didasarkan pada interview, baik yang standar maupun yang dalam (Esterberg dalam Sugiyono, 2020: 114). (3) Dokumentasi. Dokumen ini merupakan pelengkap data, karena data yang diperoleh dengan metode ini bersifat auntentik yaitu lebih terjamin kebenarannya. Dokumentasi digunakan untuk mendapatkan data-data yang tertulis dan digunakan untuk melengkapi dan mengecek data-data yang diperoleh dari wawancara (Sugiyono, 2020: 329).

Dalam melaksanakan teknik validasi data, peneliti menggunakan Trianggulasi. Trianggulasi dalam pengujian kredibitas ini diartikan sebagai pengecekan data dari berbagai sumber dengan berbagai cara, dan berbagai waktu. Dengan demikian terdapat triangulasi sumber, triangulasi teknik pengumpulan data, waktu (Sugiyono, 2020: 273).

Pada proses trianggulasi subjek, yakni dengan menguji kredibilitas data dilakukan dengan cara mengecek data yang telah diperoleh melalui beberapa sumber yang berbeda atau menggunakan minimal 3 (tiga) atau lebih informan. Adapun subjek penelitian pada penelitian ini ada 3 (tiga) partisipan yaitu Bapak Ir. Suryadi Usman sebagai ketua Badan Kesejahteraan Masjid (BKM), Ibu Rahmaini, S.P sebagai Ketua Majelis Taklim, dan Bapak Hamdani sebagai jamaah aktif masjid.

Pada proses Trianggulasi waktu, yaitu dengan melakukan proses pencarian informasi dengan melakukan penelitian dalam waktu yang berbeda pada subjek penelitian. Waktu juga sering mempengaruhi kredibilitas data. Data yang dikumpulkan dengan teknik wawancara di pagi hari pada saat narasumber masih segar, belum banyak masalah, akan memberikan data yang lebih valid sehingga kredibel. Untuk itu dalam rangka pengujian kredibilitas data dapat dilakukan dengan cara melakukan pengecekan denagn wawancara, observasi atau teknik lain dalam waktu atau situasi yang berbeda. Bila hasil uji menghasilkan data yang berbeda, maka dilakukan secara berulang-ulang sehingga sampai ditemukan kepastian datanya (Sugiyono, 2020:191).

Berikutnya adalah dengan melakukan Triangulasi teknik untuk menguji kredibilitas data dilakukan dengan cara mengecek data kepada sumber yang sama dengan teknik yang berbeda yaitu wawancara, observasi dan dokumentasi. Trianggulasi teknik 
untuk menguji kredibitas data dilakukan dengan cara mengecek data kepada sumber yang sama dengan teknik yang berbeda. Misalnya data diperoleh dengan wawancara, lalu dicek dengan observasi, dokumentasi, atau kuesioner. Bila dengan tiga teknik pengujian kredibilitas data tersebut, menghasilkan data yang berbeda-beda, maka peneliti melakukan diskusi lebih lanjut kepada sumber data yang bersangkutan atau yant lain, untuk memastikan data mana yang dianggap benar. Atau mungkin semuanya benar, karena sudut pandangnya berbeda-beda . (Sugiyono, 2020:191).

Penelitian ini dilakukan di Masjid Besar Baitul Atieq Kota Bengkulu berlokasi di J1. Meranti Raya Kelurahan Sawah Lebar Kota Bengkulu. Jumlah informan pada penelitian peranan manajemen Masjid Baitul Arieq dalam pemberdayaan ekonomi jamaah terdiri dari tiga orang yaitu Bapak Ir. Suryadi Usman sebagai ketua Badan Kesejahteraan Masjid (BKM), Ibu Rahmaini , S.P sebagai Ketua Majelis Taklim, dan Bapak Hamdani sebagai jamaah aktif masjid.

Pengecekan dokumentasi beralamatkan di Masjid Besar Baitul Atieq Sawah Lebar Kota Bengkulu. Di mulai pada tanggal 06- 20 Juli 2021. Proses analisis data dalam penelitan ini pengumpulan data dilakukan dengan mencari, mencatat, dan mengumpulkan data melalui hasil wawancara, dokumentasi, dan observasi yang terkait dengan Peranan Manajemen Masjid Besar Baitul Atieq dalam Pemberdayaan Ekonomi Jamaah. Peneliti melakukan analisis data diawali dengan tahap reduksi data. Reduksi data merupakan data mentah yang telah terkumpul yang jumlahnya sangat banyak perlu direduksi data. Reduksi berarti mengurangi data. Reduksi dilakukan dengan memilih data yang dianggap penting, merupakan data yang baru yang belum pernah dikenal, data yang unik yang berbeda dengan data yang lain dan merupakan data yang relevan dengan pertanyaan penelitian (Sugiyono, 2020:169).

Tahap berikutnya dalam analisis data setelah melakukan reduksi data yaitu display data (penyajian data). Dengan penyajian data, maka dapat mempermudah dalam memahami peranan pengurus masjid dalam melakukan manajemen pemberdayaan ekonomi jamaah yang ada di lingkungan Masjid Besar Baitul Atieq Sawah Lebar Kota Bengkulu.

Setelah data direduksi, maka langkah selanjutnya mendisplay data. Penyajian data bisa dilakukan dalam bentuk uraian singkat, bagan, hubungan antar kategori, flowchart dan sejenisnya. The most frequent form of display data for qualitative research data in the past has been narrative text'. Yang paling sering digunakan untuk menyajikan data dalam penelitian adalah dengan teks yang bersifat naratif (Miles and Huberman, dalam Sugiono, 2020:137). Dengan mendisplay data, maka akan memudahkan untuk memahami bagaimana peranan pengurus masjid dalam melakukan manajemen pemberdayaan ekonomi jamaah yang ada di lingkungan Masjid Besar Baitul Atieq Sawah Lebar Kota Bengkulu.

Tahap akhir dalam analisis data adalah penarikan kesimpulan dan verifikasi. Kesimpulan awal yang dikemukakan masih bersifat sementara, dan akan berubah bila tidak ditemukan bukti-bukti yang kuat yang mendukung pada tahap pengumpulan data berikutnya. Tetapi apabila kesimpulan yang dikemukakan pada tahap awal, didukung oleh bukti-bukti yang valid dan konsisten saat peneliti kembali ke lapangan mengumpulkan data. Jawaban dari hasil penelitian akan memberikan penjelasan dan kesimpulan atas permasalahan penelitian yang diteliti dalam penelitian (Miles and Huberman dalam Sugiyono, 2020: 141).

\section{HASIL DAN PEMBAHASAN}

Penelitian mengenai peranan manajemen masjid dalam pemberdayaan ekonomi jamaah ini dilakukan difokuskan pada satu lokasi penelitian, yaitu masjid Baitul Atieq Sawah Lebar Kota Bengkulu. Berdasarkan hasil wawancara dan observasi yang peneliti lakukan, maka ditunjukkan hasil bahwa program pemberdayaan ekonomi umat di 
bidang ekonomi dan sosial dilakukan berdasarkan keluhan dan kebutuhan bagi jamaah disekitar lingkungan Masjid Besar Baitul Atieq. pengurus masjid menggulirkan dana 20 juta untuk 10 jamaah tanpa bunga yang memiliki usaha kecil-kecilan. Usaha jamaah ini yaitu berdagang di sekitaran gedung olah raga (GOR) Sawah Lebar, pasar minggu dan tempat lainnya yang telah dapat teridentifikasi dengan baik oleh pengurus mesjid. Hasil lain pada penelitian ini yaitu pengurus masjid Baitul Atieq mengajak jamaah untuk melakukan dan belajar ternak lele. Hal ini dilakukan agar jamaah memanfaatkan lingkungan rumah serta berusaha agar ekonomi jamaah lebih stabil. Pengurus masjid memberikan bibit anak ikan lele kepada jamaah, untuk mempermudah jamaah memulai usaha ternak ikan lele.

Makna pemberdayaan ekonomi jamaah merupakan konsep pemberdayaan yang memberikan perspektif positif terhadap permanfaatan sumber daya manusia atau jamaah melalui masjid untuk kesejahteraan umat Islam. Pengembangan sumber daya manusia melalui pemberdayaan ekonomi jamaah merupakan suatu perubahan yang besar tentang revitalisasi fungsi masjid sebagai tempat pemberdayaan untuk kesejahteraan umat Muslim. Masjid merupakan pilar utama tempat melakukan pembinaan dan membangun wirausahawan yang akan menopang bagi kebangkitan dan kejayaan umat Islam.

Dengan hal itu, peranan manajemen masjid sangat diperlukan dan dilakukan dengan baik oleh takmir masjid terhadap jamaah. Ta'mir masjid (pengurus masjid) adalah sekelompok orang yang dari jamaah masjid yang mengemban amanah dan tanggung jawab terdepan dalam memakmurkan masjid (Faruq, 2010:71). Ta'mir masjid adalah lokomatif atau motor yang menggerakkan umat Islam untuk mengelola masjid, memakmurkan masjid, membina jamaah, membentuk remaja masjid dan menganekaragamkan kegiatan yang dapat dikuti oleh masyarakat sekitar (Ayub, 1996;66). Pengurus masjid Baitul Atieq dalam hal ini telah berperan aktif dalam menjalankan tugasnya sebagai salah satu sumber daya manusia dalam pemakmuran masjid. Dengan program pemanfaatan dana sosial ekonomi yang dimiliki masjid Baitul Atieq, sebagai tambahan modal bagi usaha jamaah, merupakan salah satu upaya yang baik, terutama dalam mengembangkan usaha jamaah serta mengentaskan kemiskinan ekonomi.

Kemiskinan ekonomi merupakan suatu fenomena sosial yang merupakan ketidak mampuan jamaah dalam memenuhi kebutuhan dasar hidupnya. Bahkan dapat disebutkan masalah ketidakstabilan keimanan jamaah adalah salah satunya masalah faktor perekonomian. Kemiskinan adalah masalah yang penting dan pokok dalam upaya pembangunannya. Keberagaman pandangan tentang kemiskinan menunjukan bahwa kemiskinan merupakan fenomena multi dimensi. Fenomena ini membuat pengukuran kemiskinan menjadi tidak mudah. Namun demikian, kemiskinan tetap harus diukur sebagai gambaran dan bahan pengambilan kebijakan penanggulangan kemiskinan. (Kurniasih, 2020: 278). Pemberdayaan jamaah merupakan langkah dan upaya menjadikan jamaah agar mampu mandiri dan menguasai keterampilan tertentu. Pemberdayaan ekonomi jamaah yang dilakukan oleh pengurus masjid adalah untuk memotivasi, membantu dan memanfaatkan potensi yang ada dimiliki jamaah (Hutumo, 2000). Pemberdayaan jamaah merupakan langkah dan upaya menjadikan jamaah agar mampu mandiri, terhindar dari kemiskinan dan menguasai keterampilan tertentu. Pemberdayaan ekonomi jamaah yang dilakukan oleh pengurus masjid adalah untuk memotivasi, membantu dan memanfaatkan potensi yang ada dimiliki jamaah. Program pemberdayaan jamaah adalah bagian dari program kerja di bidang ekonomi yang dimiliki Masjid Besar Baitul Atieq dengan memberikan dana pinjaman untuk modal pedagang, dan ternak lele.

Pemberdayaan adalah upaya yang membangun daya masyarakat dengan mendorong, memotivasi dan membangkitkan kesadaran akan potensi yang dimiliki serta berupaya untuk mengembangkannya. 
Pemberdayaan dimaksudkan untuk menjadikan masyarakat yang mandiri, bebas dari ketergantungan, dapat menciptakan inovasi baru, serta mampu mengembangkan perekonomiannya ke arah yang lebih baik (Nashar, 2017:17). Pemberdayaan berbasis masjid memilki perananan penting bagi pengurus masjid dalam membangun ekonomi jamaah. Pengurus masjid memahami bahwa kemakmuran masjid terletak pada kegiatan pemberdayaannya, sebagai suatu upaya yang harus diikuti dengan tetap memperkuat potensi atau daya yang dimiliki oleh setiap masyarakat (Nashar, 2017: 87).

Peranan manajemen yang dilakukan masjid Baitul Atieq dalam pemberdayaan ekonomi jamaah dinilai telah baik. Keputusan pengurus masjid Baitul Atieq dalam menjalankan program bantuan modal usaha bagi jamaah serta pelatihan pengolahan ternak lele merupakan salah satu luaran yang dapat terlihat dari hasil manajemen masjid yang baik.. Manajemen masjid merupakan proses perencanaan awal pembangunan masjid, pengurusan, pengaturan, pengorganisasian, serta pengawasan kegiatan-kegiatan di lingkungan masjid sebagai usaha untuk merealisasikan fungsi-fungsi masjid. Manajemen yang baik sangat diperlukan untuk mencapai tujuan yang telah ditetapkan dari suatu usaha (Yakub dalam Purwaningrum, 2021: 101).

Keputusan dalam menggulirkan program pemberian pinjaman modal usaha kepada jamaah serta program pelatihan usaha ikan lele tentunya diawali dengan proses perencanaan yang dilakukan pengurus masjid Baitul Atieq. Perencanaan dapat dilakukan dengan melakukan rancangan awal yang tentunya dibahas pada saat pengurus masjid melakukan rapat kepengurusan dan program masjid. Setelah itu pengorganisasian dalam pengelolaan masjid ini pada program pembedayaan ekonomi jamaah dilakukan dengan analisis dana serta kebermanfaatannya yang diorganisisir oleh pengurus masjid. Selanjutnya pelaksanaan dibuktikan dengan adanya realisasi program pemberian bantuan modal usaha dan pelatihan usaha ternak lele bagi jamaah.

Penelitian ini menunjukkan bahwa pengurus masjid di Baitul Atieq merupakan pengurus yang terbuka dan aktif. Tidak seperti beberapa fenomena yang muncul mengenai masalah dalam manajemen masjid. Dalam beberapa masjid, berdasarkan penelitian, dikemuakkan bahwa problem manajemen Masjid, antara lain. pertama pengurus tertutup, pengurus yang tertutup biasanya tidak bersedia mendengar masukan dari jamaahnya. Kedua, jamaah pasif. Seringkali jamaah tidak mau terlibat aktif dalam memakmurkan Masjid. Ketiga, miskin kegiatan. Jika Masjid dipahami sebagai tempat shalat berjamaah semata tentulah akan mematikan potensi Masjid yang lain. Keempat, pengurus berpihak pada satu golongan. Seringkali, pengurus Masjid hanya memihak pada golongan tertentu yang menjadi bagian dari jamaah Masjid. Akibat sikap diskriminasi ini, jamaah yang merasa dianaktirikan merasa enggan mengunjungi Masjid. Ini merupakan suatu hal yang ironis dalam menumbuh-kembangkan Masjid sebagai mercusuar umat Islam (Kurniawan dkk, 2021: 2-3).

Fenomena problema manajemen masjid tersebut tidak ditemukan dalam kepengurusan di masjid Baitul Atieq. Pengurus masjid Baitul Atieq dinilai terbuka, aktif, objektif serta masjid Baitul Atieq memiliki jaah yang aktif. Komponen ini yang menjadi salah satu alasan bahwa pemberdayaan ekonomi masyarakat di masjid Baitul Atieq berjalan dengan baik, ditunjukkan dengan program pemberian pinjaman modal untuk usaha bagi jamaah Baitul Atieq serta pelatihan ternal lele bagi jamaah Baitul Atieq dapat berjalan.

\section{KESIMPULAN}

Pengurus masjid Besar Baitul Atieq Sawah Lebar Kota Bengkulu memiliki suatu program pemberdayaan ekonomi jamaah di bidang ekonomi dan sosial yang memberikan manfaat bagi jamaah. Pengurus masjid melalui program ekonomi dan sosial memberikan 
talangan dana untuk masyarakat di sekitaran masjid yang ingin membuka usaha supaya memiliki modal untuk memulai usaha, talangan dana untuk masyarakat disekitar masjid yaitu 10 pedagang dengan masing-masing pedagang mendapatkan 2 juta rupiah tanpa bunga, dan pengurus masjid juga melakukan program ternak ikan lele yang mana jamaah diberikan pinjaman bibit ikan lele untuk ternak lele.

\section{DAFTAR PUSTAKA}

Ayub,E, Muhsin MK, Ramlan Mardjoned. 1996. Manajemen Masjid: Petunjuk Praktis bagi para pengurus. Depok. Gema Insani.

Asrori, Kiswanto, Fachrurrozie, \& Amal, M. (2020). Development of Mosque Accounting Information Systems Based on Non-profit Entity Reporting Standards and Sharia Compliance: A Case Study at the $X$ Great Mosque. Jurnal Dinamika Akuntansi, 12(1), 55-67. doi:https://doi. org/10.15294/jda.v12i1.23930

Faruq Asadullah. 2010. Panduan Lengkap Mengelola dan Memakmurkan Masjid. Solo. Pustaka Arafah.

Hutumo, Mardi Yatmo. 2000. Pemberdayaan Masyarakat dalam Bidang Ekonomi: Tinjauan Teotirik dan Impelemntasi. Seminar Pemberdayaan Masyarakat. Bappenas. Jakarta.

Kurniasih, Erni Panca. (2020). Dampak Pandemi Covid 19 Terhadap Penurunan Kesejahteraan Masyarakat Kota Pontianak. Prosiding Seminar Akademik Tahunan Ilmu Ekonomi dan Studi Pembangunan 2020. ISBN: 978-602-53460-5-7

Kurniawan, Dedi., Depi Putri., Sumraini. 2021. Implementasi Manajemen Masjid Agung As-Salam Kota Lubuklinggau. Al- Idarah: Jurnal
Manajemen Dakwah. 2(1), 1-13. Url: $\quad$ https://e-journal.iai-alazhaar.ac.id/index.php/idaroh/ index

Mustaming, S. (2012, 26). Fungsi Masjid dan Peranannya Sebagai Pusat Ibadah dan Pembinaan Umat. Retrieved 3 28, 2016,from Website Kemenag Sultra: http:/sultra.kemenag.go.id/file/Tul isan/zeam1328534716.pdf.

Nashar, SE. 2017. Pemberdayaan Ekonomi Generasi Muda Dimulai Dari Halaman Masjid. Pamekasan. Duta Media.

Purwaningrum, Septiana. (2021). Optimalisasi Peran Masjid Sebagai Sarana Ibadah Dan Pendidikan Islam (Studi Kasus Di Masjid Namira Lamongan). Jurnal Inovatif. 7 (1), 96-116. eISSN 2598-3172

Saifullah Yusuf, "Masjid basis Pengentasan Kemiskinan",

Republika. 5 Januari 2007.

Sugiyuno. 2020. Metode Penelitian Kualitatif. Bandung. Alfabeta CV. Sugiyuno. 2015. Metode Penelitian Pendidikan: Pendekatan Kuantitatif, Kualitatif, dan RED. Bandung. Alfabeta CV.

Suryani, Evi. (2021). Analisis Dampak Covid-19 Terhadap Umkm (Studi Kasus: Home Industri Klepon Di Kota Baru Driyorejo). JIP: Jurnal Inovasi Penelitian. 1 (8), 1591 - 1596. ISSN 2722-9475 (Cetak). ISSN 27229467 (Online) 